\title{
Influence of harvest season, cutting frequency and nitrogen fertilization of mountain meadows on yield, floristic composition and protein content of herbage
}

\author{
Olívio Bochi Brum ${ }^{1,2}$, Secundino López ${ }^{1 *}$, Ricardo García $^{1}$, Sonia Andrés ${ }^{1}$, Alfredo Calleja ${ }^{1}$ \\ ${ }^{1}$ Departamento de Producción Animal, Universidad de León, E-24071 León, Spain. \\ 2 Universidade Regional Integrada do Alto Uruguai e das Missões - URI - Campus de Santiago, Departamento de Ciências Agrárias, \\ Av. Batista Bonotto Sobrinho S/N, CEP: 97700-000 Santiago, RS, Brasil.
}

\begin{abstract}
The aim of the present study was to investigate the influence of cutting frequency, harvest season and nitrogen fertilization on yield and floristic composition of the herbage harvested from a mountain meadow. The meadow was divided into 22 plots, each receiving a different N P K fertilization treatment. The study lasted seven years, and during the first three years (1985-1987) each plot was harvested twice per year (June and September) according to a traditional harvest system, whereas in the years 1989-1991 each plot was harvested three times per year (spring, summer and autumn) following a more intensive harvest system. Nitrogen fertilizer favoured the development of the grasses in spring, thus reducing the proportion of legumes in the two cut harvest system, whereas grasses reached an advanced stage of maturity before the first cut in late June. However, the three cut harvest system entailed an earlier first cut in spring. As a result, the production of legume biomass was significantly increased both in the first cut and in the subsequent regrowths. No significant response in total herbage production to the $\mathrm{N}$ fertilizer was observed in the more intensive harvest system. Therefore, the three cut harvest system without nitrogen fertilization seemed to be the most suitable practice for the management of these botanically-complex mountain meadows. These results may contribute to design fertilization and management practices of mountain hay meadows to optimize their productivity and sustainability.
\end{abstract}

Key Words: chemical composition, cutting frequency, floristic composition, herbage yield, nitrogen fertilization

\section{Influência da estação da colheita, freqüência de corte e fertilização nitrogenada de prados de montanha sobre o rendimento, a composição botânica e o conteúdo de proteína da forragem}

\begin{abstract}
RESUMO - O objetivo neste estudo foi investigar a influência da freqüência de corte, da estação de colheita e da adubação nitrogenada no rendimento e na composição botânica da forragem recolhida de um prado de montanha. O prado foi dividido em 22 parcelas, cada uma com nível de fertilização N P K. O estudo durou sete anos e, durante os três primeiros (1985-1987), cada parcela foi cortada duas vezes por ano (junho e setembro), seguindo um sistema de aproveitamento tradicional, ao passo que, nos anos 1989-1991, cada parcela foi cortada três vezes por ano (primavera, verão e outono), seguindo um sistema de aproveitamento mais intensivo. O fertilizante nitrogenado favoreceu o desenvolvimento das gramíneas na primavera reduzindo a proporção de leguminosas no sistema de dois cortes anuais, de modo que as gramíneas alcançaram etapa avançada de maturidade antes do primeiro corte, ao final do mês de junho. No entanto, com o sistema de três cortes anuais, o primeiro corte foi realizado mais cedo, na primavera. Conseqüentemente, a produção da biomassa de leguminosas aumentou significativamente, tanto no primeiro corte como nos rebrotes subseqüentes. Nenhum efeito significativo na produção total de forragem em resposta à fertilização nitrogenada foi observado no sistema de aproveitamento mais intensivo. Portanto, o sistema de três cortes, sem fertilização nitrogenada, parece ser a prática mais conveniente para o manejo desses prados de montanha, botanicamente complexos. Os resultados obtidos neste estudo podem contribuir para projetos de fertilização e práticas de manejo de prados de montanha, utilizados para produção de feno, para otimizar sua produtividade e sustentabilidade.
\end{abstract}

Palavras-chave: composição botânica, composição química, fertilização nitrogenada, freqüência de corte, produção de forragem 


\section{Introduction}

Mountain meadows are an important source of feed for livestock, especially when harvested as hay for the winter period. Low soil fertility is a major factor limiting forage production with $\mathrm{N}$ being the most limiting nutrient. Highland grasslands in temperate regions rely on $\mathrm{N}$ fixed biologically (i.e. reduction of atmospheric nitrogen $\mathrm{N}_{2}$ to ammonia) as the main source of $\mathrm{N}$ (Bergersen 1973). In early spring plants accelerate their development but may undergo some $\mathrm{N}$ deficiency, due to low temperatures that depress $\mathrm{N}$ fixation. In farm animal production systems based on intensively managed grasslands, this biological $\mathrm{N}$ input may be insufficient for pasture and animal demands, and nitrogen fertilization may be required in order to avoid a reduction of the leaf expansion rate and, consequently, the total herbage production (Mazzanti et al., 1994; Belanger \& McQueen 1998; Madakadze et al., 1999). Nevertheless this may be an expensive alternative which increases the risk of environmental damage and counteracts grassland biodiversity. To attain a sustainable system of utilization of mountain hay meadows, an increase in productivity through fertilization and management practices is desirable, providing it is compatible with important environmental issues such as the biodiversity in species-rich meadows or the risk of pollution of groundwater (Peyraud \& Astigarraga, 1998; Duru \& Delaby, 2003; Topp \& McGechan, 2003).

The effects of $\mathrm{N}$ fertilization on intensively managed swards have been studied extensively. However, much less is known about $\mathrm{N}$ fertilization of montane-alpine grasslands, where the effects of $\mathrm{N}$ fertilization need to be studied under different harvest systems determining the cutting frequency and the cutting date for each harvest season, factors with a significant influence on the plant maturity stage at harvest (Keady \& O’Kiely, 1998; Duru \& Delaby, 2003). Thus, the aim of the present study was to evaluate the influence of the harvest season, cutting frequency and $\mathrm{N}$ fertilization rate on yield and chemical or floristic composition of the herbage harvested from permanent mountain meadows. This study provides an insight into the effects of $\mathrm{N}$ fertilization on species-rich mountain meadows in order to establish the optimal fertilization rate under different cutting frequencies for the design of strategies of management allowing a more sustainable land use system.

\section{Material and Methods}

The study was conducted on an irrigated permanent meadow of 3,600 $\mathrm{m}^{2}$ located in north-western Spain (Las Salas, León; $42^{\circ} 56^{\prime} \mathrm{N}, 5^{\circ} 6^{\prime} \mathrm{W}$ ) at an altitude of 1,010 m above sea level. According to the Köppen Climate Classification System the area of study is characterized by a temperate climate with a mild summer dry season (with characteristics of both the Csb and Cfb types of the classification). Monthly average temperatures range from a minimum of $1.2^{\circ} \mathrm{C}$ (January) to $16.2^{\circ} \mathrm{C}$ (July), and average rainfall is $1,287 \mathrm{~mm} /$ year (with an average seasonal distribution of $417 \mathrm{~mm}$ in winter, $263 \mathrm{~mm}$ in spring, $142 \mathrm{~mm}$ in summer and $465 \mathrm{~mm}$ in autumn). With these agro-climatic conditions, the growing season of the herbaceous vegetation starts in late March, when the average temperature is above $5^{\circ} \mathrm{C}$. In most years the rainfall in spring is enough for the optimal growth of the herbage before the first harvest (in late spring or early summer). In the driest months (July and August), the precipitations are scarce (some years less than $30 \mathrm{~mm}$ ), and it is necessary to irrigate the meadow every 10-15 days. In relation to the soil major characteristics (determined following conventional methods (MAFF 1986)), the texture is clay-loam, $\mathrm{pH}\left(\mathrm{in}_{2} \mathrm{O}\right.$ ) is slightly acid (about 6.2), with moderate concentrations of organic matter $(123 \mathrm{~g} / \mathrm{kg}$ soil), nitrogen (6.2 g/kg soil) and calcium ( $4.7 \mathrm{~g} \mathrm{CaO} / \mathrm{kg}$ soil), but it is poor in phosphorus ( $87.5 \mathrm{mg} \mathrm{P}_{2} \mathrm{O}_{5} / \mathrm{kg}$ soil) and potassium (170 $\mathrm{mg} \mathrm{K}_{2} \mathrm{O} / \mathrm{kg}$ soil). Nitrogen was measured regularly in soil during the course of the experiment. There were small year to year variations in nitrogen concentration in soil, and differences in soil nitrogen between control and fertilized plots were not significant (data not shown). The soil on the site is a Typic Udifluvent according to USDA (Soil Survey Staff, 2006) or a Fluvisol Gleyic based on the FAO classification (FAO-ISRIC-ISSS, 1998).

From a botanical point of view, this meadow is a plant community classified within the vegetation type Arrhenatheretalia, i.e. pastures and meadows on welldrained, relatively fertile mineral soils (Rodwell et al., 2000). Predominant forage species are Alopecurus pratensis (L.), Anthoxanthum odoratum (L.), Arrhenatherum elatius (L.) Beauv. ex. J. \& C. Pres (L.), Bromus hordeaceus (L.), Cynosurus cristatus (L.), Dactylis glomerata (L.), Festuca pratensis Huds., Holcus lanatus (L.), Lolium perenne (L.), Poa pratensis (L.), Poa trivialis (L.), Trisetum flavescens (L.) Beauv., Trifolium pratense (L.), Trifolium repens (L.), Bellis perennis (L.), Carum carvi (L.), Centaurea nigra (L.), Cerastium fontanum Beaumg., Plantago lanceolata (L.), Ranunculus bulbosus (L.), Rumex acetosa (L.), Taraxacum officinale Weber and Veronica arvensis (L.)

A fertilization assay has been conducted in the meadow since 1978. The meadow was divided into $24.5 \mathrm{~m}^{2}$ plots $(7 \mathrm{~m} \times 3.5 \mathrm{~m})$ to which each fertilization treatment was 
randomly assigned. The experiment comprised three fertilizers (N, P and K) and four rates of application of each fertilizer, resulting in the 22 combinations of the three different fertilizers (Table 1). In addition to the control treatments (no fertilizer), the other treatments resulted from the application of each fertilizer separately at different rates (nine fertilizers), and the binary (nine mixtures) and tertiary (three mixtures) combinations of fertilizers at different rates of application.

Until 1988 the meadow was harvested twice each year in late June and mid September following a traditional harvest system. From 1988 onwards, three cuts (late spring (31 May-10 June), mid summer (20-31 July) and early autumn (27 September-6 October) were performed each year according to a more intensive system. The study presented herein was carried out with the samples obtained in 1985, 1986 and 1987 ( 22 fertilization treatments $\times 2$ cuts $\times 3$ years $=132$ samples $)$ and those obtained in 1989, 1990 and 1991 ( 22 fertilization treatments $\times 3$ cuts $\times 3$ years $=198$ samples). Samples obtained in 1988 were not used in the study, considering this year as a transitional time between both harvest systems. With this design, it was possible to study the effect of fertilizer application and the differences between harvest seasons within each system, and also to compare the herbage yield and quality obtained under each regime of exploitation of the meadow.

The fertilizers used to prepare the different combinations were calcium ammonium nitrate, single superphosphate

Table 1 - Rates of the different fertilizers for each experimental treatment

\begin{tabular}{lccc}
\hline Treatment & $\mathrm{N}$ & $\begin{array}{c}\mathrm{P}_{2} \mathrm{O}_{5} \\
\text { (kg/ha }\end{array}$ & $\begin{array}{c}\mathrm{K}_{2} \mathrm{O} \\
\text { per year) }\end{array}$ \\
\hline N0-P0-K0 & 0 & 0 & 0 \\
N0-P0-K1 & 0 & 0 & 60 \\
N0-P0-K2 & 0 & 0 & 120 \\
N0-P0-K3 & 0 & 0 & 180 \\
N0-P1-K0 & 0 & 80 & 0 \\
N0-P1-K1 & 0 & 80 & 60 \\
N0-P2-K0 & 0 & 160 & 0 \\
N0-P2-K2 & 0 & 160 & 120 \\
N0-P3-K0 & 0 & 240 & 0 \\
N0-P3-K3 & 0 & 240 & 180 \\
N1-P0-K0 & 60 & 0 & 0 \\
N1-P0-K1 & 60 & 0 & 60 \\
N1-P1-K0 & 60 & 80 & 0 \\
N1-P1-K1 & 60 & 80 & 60 \\
N2-P0-K0 & 120 & 0 & 0 \\
N2-P0-K2 & 120 & 0 & 120 \\
N2-P2-K0 & 120 & 160 & 0 \\
N2-P2-K2 & 120 & 160 & 120 \\
N3-P0-K0 & 180 & 0 & 0 \\
N3-P0-K3 & 180 & 0 & 180 \\
N3-P3-K0 & 180 & 240 & 180 \\
N3-P3-K3 & 180 & 240 & \\
\hline
\end{tabular}

and potassium chloride. The fertilizers were mixed in the laboratory to obtain the different combinations. Each fertilizer mixture was spread by hand over each plot in a single application. All the plots were fertilized at the same time in early spring (end of March or beginning of April), just as the sward began to grow.

Harvesting of herbage was conducted using a sickle bar motor-mower for cutting hay (bar $1.10 \mathrm{~m}$ wide). First, all the plots were delimited by cutting and discarding the herbage at the borders between two adjacent plots. Then, width and length of each delimited plot were measured (plot area effectively measured after discarding borders ranged from 12 to $15 \mathrm{~m}^{2}$ ), and all the herbage enclosed was cut (stubble height of approximately $3 \mathrm{~cm}$ ) and weighed using a portable balance with a precision of $\pm 10 \mathrm{~g}$. Two herbage samples (ca. $1 \mathrm{~kg}$ herbage each sample) were taken from each plot, one for dry matter (DM) and crude protein (CP) determinations, and the other one to determine the floristic composition (proportions of grasses, legumes and other species). Both samples were collected in plastic bags, immediately taken to the laboratory, and frozen at $-18^{\circ} \mathrm{C}$.

One herbage sample from each plot was defrosted, oven-dried at $60^{\circ} \mathrm{C}$ and ground to pass $1 \mathrm{~mm}$ screen. CP content was determined by the Kjeldahl procedure (method ID 984.13) outlined by the AOAC (1995). The other sample was defrosted and then was hand-separated into grasses, legumes and "other herbs". These fractions were oven dried at $60^{\circ} \mathrm{C}$ to calculate the proportions (on DM basis) of the different botanical groups in each sample.

Statistical analysis in relation to the chemical and floristic composition was performed separately for the two different harvest systems (either two or three cuts per year), given the different number of degrees of freedom in each case. However, the experimental design was similar in both cases, with treatments arranged in a splitplot structure in a randomized complete block design with three replications, with $\mathrm{N}$ fertilization rate $(0,60,120$ or $180 \mathrm{~kg} / \mathrm{ha}$ per year) as the main plot, and harvest season (July or September in the traditional management system with two harvests per year, and spring, summer or autumn in the more intensive system with three cuts per year) as the split-plot. The whole-plot error term was experimental plot and the subplot error term was the interaction between plot and harvest season, both as random effects. Linear and quadratic effects of the rate of $\mathrm{N}$ fertilization were assessed by partitioning variance using orthogonal polynomials (Steel \& Torrie, 1980). Analysis of variance was carried out using the SAS Statistical Software Package (SAS, 1999). 


\section{Results and Discussion}

In the herbage harvested in the first cut (June in Table 2; and spring in Table 3), the proportion of grasses was significantly increased, the relative proportion of legumes was decreased and no significant changes were observed in the proportion of the other herbs with high rates of nitrogen fertilization. The effect of $\mathrm{N}$ fertilization on floristic composition was similar in the case of the herbage harvested in the regrowths for both frequencies of harvest (September in Table 2, and summer or autumn in Table 3), with the exception of a significant increase $(\mathrm{P}<0.05)$ in the proportion of other herbs with the application of $120 \mathrm{~kg} \mathrm{~N} / \mathrm{ha}$ per year. Our results are in agreement with those previously described by different authors (Myklestad \& Szetersdal, 2003; Luo et al., 2006; Hejcman et al., 2007), and can be explained because spring grasse s start to grow when soil temperature reaches $4-6^{\circ} \mathrm{C}$ (Robson et al., 1988), so the application of $\mathrm{N}$ fertilizer in early spring promotes a faster growth and stem elongation and earlier maturity of leaves of grass species (Wilson, 1982). This effect is more important in grasses such as Lolium, Dactylis, Festuca and Phleum spp., whereas other grasses (Agrostis, Poa) may be more productive than perennial ryegrass at low rates of $\mathrm{N}$ input (Bailey, 2000). In contrast, spring legumes start to grow later after winter, and their growth is restricted by more mature grasses that are in a better position to compete for environmental resources required for plant growth, such as light. Woledge (1977) observed that at the end of the spring growing season, legumes were shaded by high mature grasses, hindering photosynthetic activity and hampering growth of legumes. This effect is exacerbated with the accelerated grass growth raised by $\mathrm{N}$ fertilization, and explains why legumes were almost absent in plots receiving the highest $\mathrm{N}$ fertilization rate (Tables 2 and 3).

It is well known that nitrogen fertilizers have a significant effect on CP content of the herbage. In agreement with the results described herein (June in Table 2 and spring in Table 3), McCarrick and Wilson (1966) observed an increase in $\mathrm{CP}$ content in the first cut herbage when applying high rates of $\mathrm{N}$ fertilizer on a permanent pasture (mixture of grasses and white clover), despite of promoting a decrease in the clover content. Increases in $\mathrm{N}$ content as a consequence of $\mathrm{N}$ fertilization were also detected by other authors in herbage harvested in the first cut after the spring growing cycle (Delagarde et al., 1997; Keady \& O’Kiely, 1998; McCaughey \& Simons, 1998; Madakadze et al., 1999; Duru, 2003; Duru \& Delaby, 2003; Elliott \& Abbott, 2003a). This could be due, at least in part, to higher contents of non-protein nitrogen (NPN). The main components of the NPN fraction are amino acids, and amides, such as glutamine and asparagine, which are involved in protein synthesis. Other NPN compounds are nitrates that increase in grass with high rates of $\mathrm{N}$ application (Cherney et al., 1995; Lovett et al., 2004; Burner\& MacKown, 2006) and may be toxic for grazing animals. This NPN fraction of herbage is affected by

Table 2 - Floristic composition and crude protein content (g/kg DM) of the herbage obtained in each harvest season with different rates of nitrogen fertilization in a system with two annual harvests

\begin{tabular}{|c|c|c|c|c|c|}
\hline Harvest season & $\mathrm{N}$ fertilization rate (kg/ha per year) & Grasses & Legumes & Other herbs & Crude protein \\
\hline \multirow[t]{4}{*}{ June } & 0 & 717 & 111 & 172 & 91 \\
\hline & 60 & 777 & 58 & 165 & 89 \\
\hline & 120 & 821 & 20 & 159 & 95 \\
\hline & 180 & 892 & 6 & 102 & 118 \\
\hline \multirow[t]{4}{*}{ September } & 0 & 410 & 245 & 345 & 139 \\
\hline & 60 & 513 & 146 & 341 & 135 \\
\hline & 120 & 473 & 65 & 462 & 119 \\
\hline & 180 & 667 & 10 & 323 & 121 \\
\hline S.E.D ${ }_{C}$ & & 16.8 & 14.5 & 21.6 & 3.1 \\
\hline S.E.D $\mathrm{D}_{\mathrm{f}}$ & & 36.9 & 21.1 & 38.2 & 4.8 \\
\hline \multicolumn{6}{|l|}{$P$ value } \\
\hline \multirow[t]{3}{*}{ June } & $\mathrm{N}$ fertilization & $<0.001$ & $<0.001$ & 0.110 & $<0.001$ \\
\hline & Linear & $<0.001$ & $<0.001$ & 0.141 & $<0.001$ \\
\hline & Quadratic & 0.348 & 0.029 & 0.917 & 0.002 \\
\hline \multirow[t]{3}{*}{ September } & $\mathrm{N}$ fertilization & $<0.001$ & $<0.001$ & 0.053 & 0.004 \\
\hline & Linear & $<0.001$ & $<0.001$ & 0.928 & 0.006 \\
\hline & Quadratic & 0.300 & 0.269 & 0.122 & 0.488 \\
\hline
\end{tabular}

S.E. $D_{C}$ - Standard error of the difference for the comparison between harvest seasons within the same rate of $\mathrm{N}$ fertilization.

S.E. $D_{f}$ - Standard error of the difference for the comparison among the different rates of $\mathrm{N}$ fertilization within the same harvest season. 
Table 3 - Floristic composition and crude protein content (g/kg DM) of the herbage obtained in each harvest season with different rates of nitrogen fertilization in a system with three annual harvests

\begin{tabular}{|c|c|c|c|c|c|}
\hline Harvest season & $\mathrm{N}$ fertilization rate (kg/ha per year) & Grasses & Legumes & Other herbs & Crude protein \\
\hline \multirow[t]{4}{*}{ Spring } & 0 & 694 & 142 & 164 & 106 \\
\hline & 60 & 783 & 63 & 154 & 110 \\
\hline & 120 & 732 & 39 & 229 & 122 \\
\hline & 180 & 835 & 27 & 138 & 134 \\
\hline \multirow[t]{4}{*}{ Summer } & 0 & 360 & 283 & 357 & 164 \\
\hline & 60 & 503 & 163 & 334 & 152 \\
\hline & 120 & 457 & 73 & 470 & 148 \\
\hline & 180 & 599 & 53 & 348 & 160 \\
\hline \multirow[t]{4}{*}{ Autumn } & 0 & 471 & 218 & 311 & 157 \\
\hline & 60 & 505 & 182 & 313 & 155 \\
\hline & 120 & 471 & 92 & 437 & 144 \\
\hline & 180 & 597 & 76 & 327 & 143 \\
\hline S.E.D ${ }_{C}$ & & 27.5 & 18.7 & 22.4 & 4.0 \\
\hline S.E.D $f$ & & 42.0 & 33.3 & 42.5 & 6.9 \\
\hline \multicolumn{6}{|l|}{$P$ value } \\
\hline \multirow[t]{3}{*}{ Spring } & $\mathrm{N}$ fertilization & 0.001 & 0.003 & 0.053 & 0.005 \\
\hline & Linear & 0.007 & 0.003 & 0.572 & 0.003 \\
\hline & Quadratic & 0.931 & 0.636 & 0.661 & 0.983 \\
\hline \multirow[t]{3}{*}{ Summer } & $\mathrm{N}$ fertilization & 0.002 & $<0.001$ & 0.073 & 0.217 \\
\hline & Linear & 0.005 & $<0.001$ & 0.476 & 0.679 \\
\hline & Quadratic & 0.850 & 0.352 & 0.521 & 0.184 \\
\hline \multirow[t]{3}{*}{ Autumn } & $\mathrm{N}$ fertilization & 0.016 & $<0.001$ & 0.074 & 0.003 \\
\hline & Linear & 0.008 & $<0.001$ & 0.476 & 0.679 \\
\hline & Quadratic & 0.204 & 0.522 & 0.213 & 0.855 \\
\hline
\end{tabular}

S.E. $D_{C}$ - Standard error of the difference for the comparison between harvest seasons within the same rate of $\mathrm{N}$ fertilization.

S.E. $D_{f}$ - Standard error of the difference for the comparison among the different rates of $\mathrm{N}$ fertilization within the same harvest season.

the physiological stage of the plant and, generally, increases when growth conditions are more favourable and decreases with plant maturity. With high $\mathrm{N}$ fertilizer applications, NPN could have increased in grasses owing to an important absorption of $\mathrm{N}$ at the early stages and during the period of growth (Peyraud \& Astigarraga, 1998). On the other hand, $\mathrm{N}$ fertilization reduces the proportion of leaves and leads to a faster increase in stem mass in both grasses and legumes (Boval et al., 2002). As stems contain less $\mathrm{N}$ than leaves, the higher CP content of first-cut herbage in the fertilized plots cannot be attributed to the increased proportion of stems.

During summer growth, conditions are more favourable (longer days and higher temperatures) for legume species (Davidson \& Robson, 1984), and hence the proportion of legumes was greater in the herbage collected in the regrowths (Tables 2 and 3). However, even under these more favourable conditions, the growth of legumes was hampered at the highest rates of $\mathrm{N}$ fertilizer application. Although legumes are able to use available soil N, they appear to be outperformed by grasses in the competition for that nutrient in grass-clover mixed swards due to their shorter root system (Wilman \& Fisher, 1996). Additionally, there is evidence of detrimental effects of $\mathrm{N}$ supply on the nitrogen fixing bacteria of the nodulated legumes (Carlsson \& Huss-Danell, 2003; Oliveira et al., 2004). All these factors could explain the decrease in legume proportion and, consequently, in CP content of the herbage collected in the regrowths associated to the application of a higher amount of $\mathrm{N}$ fertilizer (Tables 2 and 3). These results are in agreement with Duru \& Delaby (2003) who observed a trend towards a decrease in the $\mathrm{N}$ index of regrowths of grazing pastures in response to the $\mathrm{N}$ fertilization. Also, this change in floristic composition may be markedly affected by cutting or grazing, as frequent cutting is more favourable for short- than for tall-growing species (Frame et al., 1998).

As a result of the effect of $\mathrm{N}$ fertilization on the floristic composition of the herbage collected in each harvest season, the yields of grass and legume biomass were significantly affected, as grasses increased and legume biomass decreased $(\mathrm{kg} / \mathrm{ha})$ with increasing $\mathrm{N}$ fertilization rate 
(Tables 4 and 5). This effect was also observed in the herbage collected in first cuts and regrowths in both harvest systems, with larger differences among $\mathrm{N}$ fertilization rates in the two annual harvest regime (Tables 4 and 5). As a consequence, whilst the DM production ( $\mathrm{kg} / \mathrm{ha}$ ) in the first cuts (June and spring) increased with $\mathrm{N}$ fertilization, total $\mathrm{DM}$ production in the regrowths was not affected by $\mathrm{N}$ fertilization or tended to decrease.

Similarly, CP production ( $\mathrm{kg} / \mathrm{ha}$ ) increased in the first cuts and decreased in the regrowths (Tables 4 and 5) in response to the $\mathrm{N}$ application because of the negative effects of this fertilizer on the development of legumes (Honsova et al., 2007). Other authors have also observed increases in DM production (Keady \& O'Kiely, 1998; Madakadze et al., 1999; Elliott \& Abbott, 2003a; Aydin \& Uzun, 2005; Comakli et al., 2005; Mueller et al., 2005) and CP production (McCaughey \& Simons, 1998) in the first cuts in response to $\mathrm{N}$ fertilization. In agreement with our results (Table 5), McCaughey \& Simons (1998) and Keady
\& O’Kiely (1998) reported no significant effects of $N$ fertilization on DM herbage production in the regrowths.

Regardless the effects of $\mathrm{N}$ fertilization on DM and $\mathrm{CP}$ production in each harvest season, there was no significant effect of $\mathrm{N}$ fertilization on total annual production of DM or CP ( $\mathrm{kg} /$ ha per year) in the more intensive harvest system (Table 5) whereas in the traditional system (Table 4) DM production was significantly increased in the fertilized paddocks, and CP production was higher in the plots receiving the highest rate of $\mathrm{N}$ fertilizer (Table 4).

At the same rate of $\mathrm{N}$ fertilization there were small differences between harvest systems (two vs. three cuts) in the total annual DM production (Tables 4 and 5). However, increasing cutting frequency resulted in an earlier first cut (Elliott and Abbott 2003b) with a better quality (more legumes and higher $\mathrm{CP}$ content), and made it possible to obtain another two harvests from subsequent regrowths. On the contrary, in the two annual harvest system the first cut was delayed, being its contribution to the total annual

Table 4 - Yield (kg/ha) obtained in each harvest season and total annual production with different rates of nitrogen fertilization in a system with two annual harvests

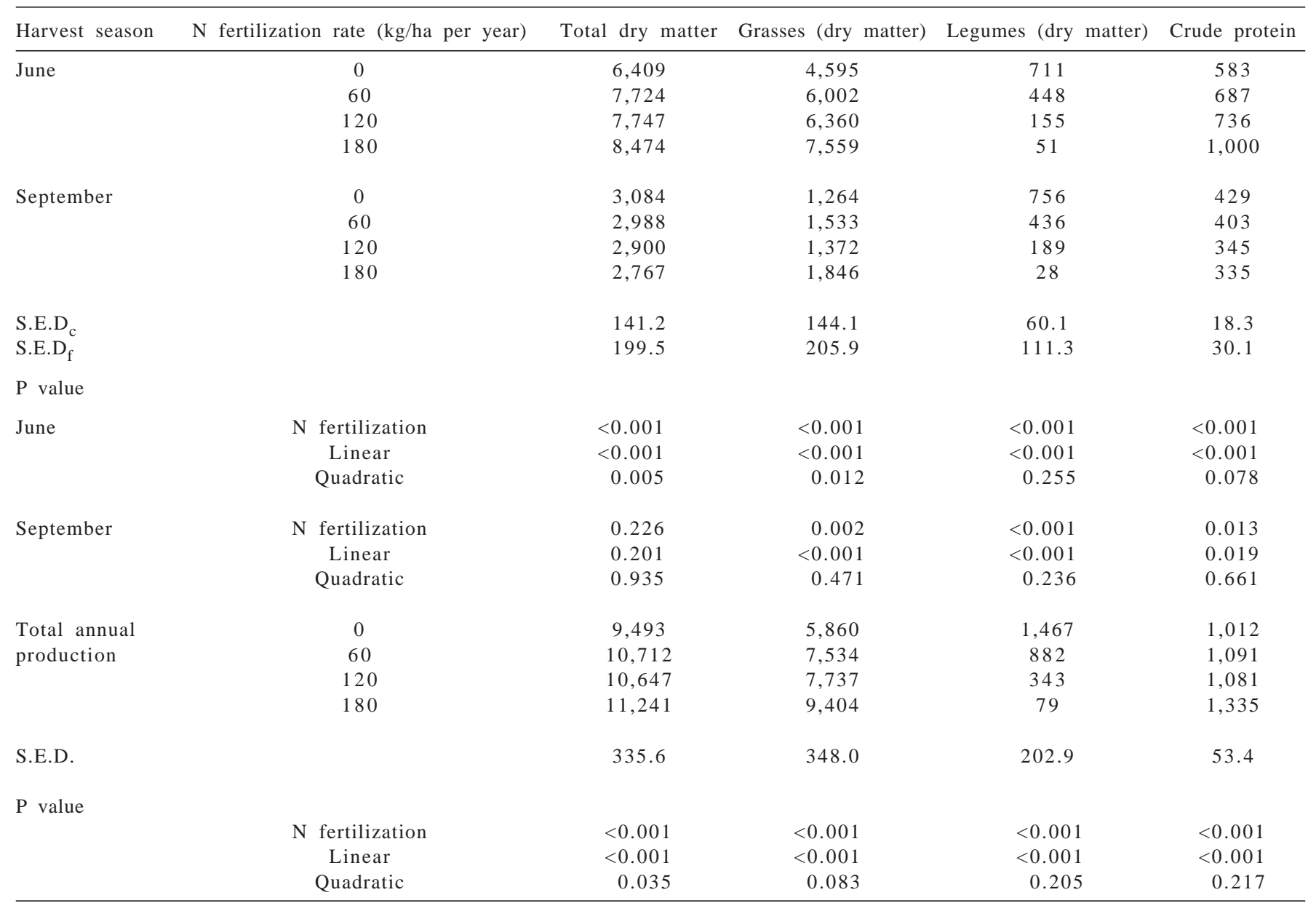

S.E. $D_{C}$ - Standard error of the difference for the comparison between harvest seasons within the same rate of $\mathrm{N}$ fertilization.

S.E. $D_{f}$ - Standard error of the difference for the comparison among the different rates of $\mathrm{N}$ fertilization within the same harvest season.

S.E.D. - Standard error of the difference. 
Table 5 - Yield (kg/ha) obtained in each harvest season and total annual production with different rates of nitrogen fertilization in a system with three annual harvests

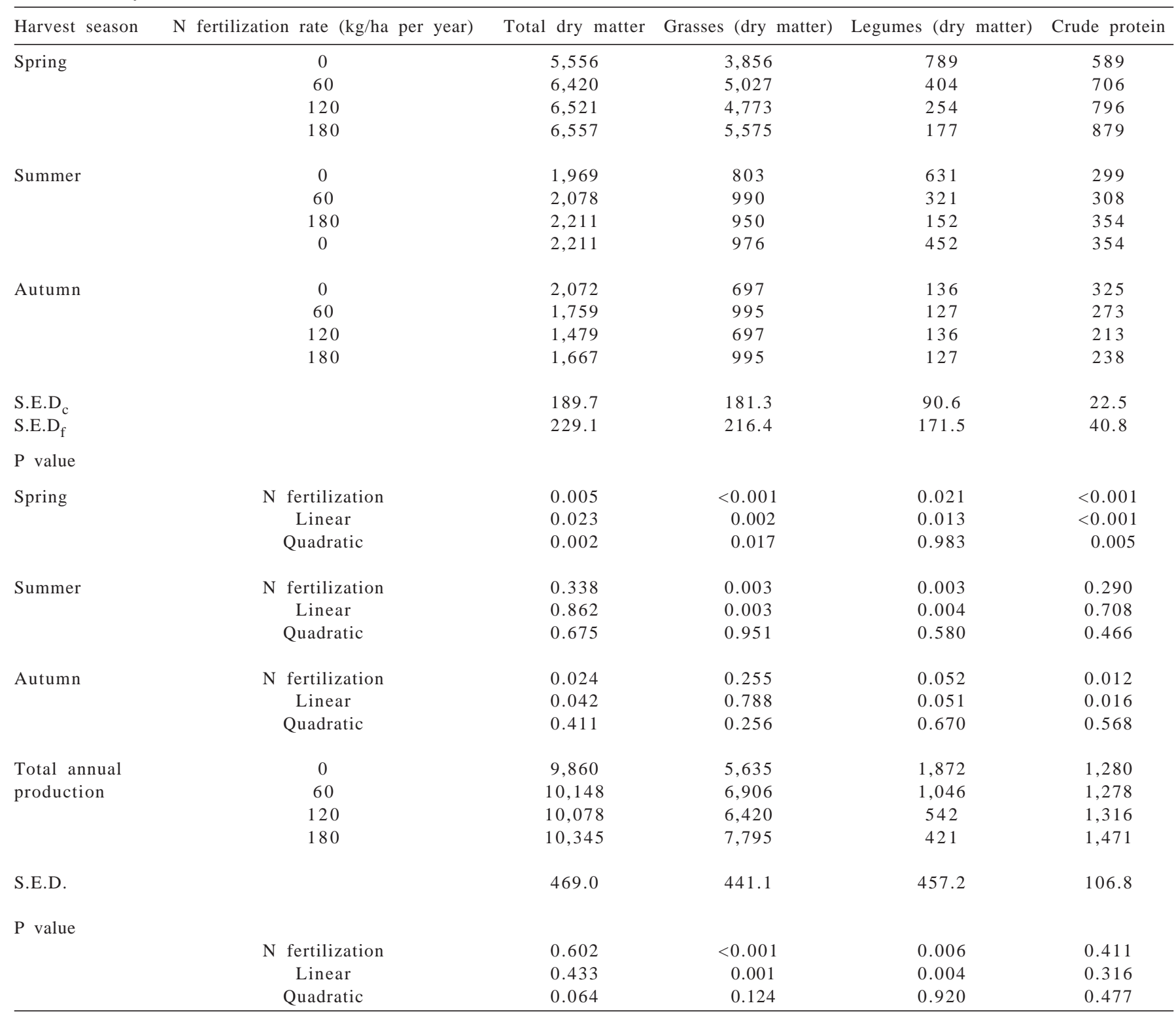

S.E. $\mathrm{D}_{\mathrm{C}}$ - Standard error of the difference for the comparison between harvest seasons within the same rate of $\mathrm{N}$ fertilization.

S.E. $D_{f}$ - Standard error of the difference for the comparison among the different rates of $\mathrm{N}$ fertilization within the same harvest season.

S.E.D. - Standard error of the difference.

production greater (Table 4) compared with that in the more intensive system (Table 5).

\section{Conclusions}

The optimal rate of nitrogen fertilization may be different if the cutting frequency is increased, as our results have shown that whereas nitrogen fertilization (up to $60 \mathrm{~kg} \mathrm{~N} /$ ha per year) resulted in higher DM productions when the meadow was harvested twice per year, no significant response was observed to the $\mathrm{N}$ fertilizer in the three cut harvest system. Additionally, the negative effect of nitrogen fertilization on the growth of legume species was more noticeable in the two cut harvest system, whereas the earlier first harvest in the three cut system avoids legumes to be hindered by grasses. Taking into account holistically productive, economical and environmental issues, the three annual harvest system without nitrogen fertilization seems to be the most suitable practice for the management of these botanically-complex mountain meadows. With this strategy, better quality forage (legumes, $\mathrm{CP}$ ) may be obtained without an adverse effect on physical environment, contributing to the sustainability of mountain hay meadows. 


\section{Acknowledgments}

Financial support by INIA-Junta de Castilla y León (Project OT00-037-C17-09) and by Junta de Castilla y LeónF.S.E. (Projects GR158 and LE29/03) is gratefully acknowledged.

\section{Literature Cited}

ASSOCIATION OF OFFICIAL ANALYTICAL CHEMISTRY AOAC. Official methods of analysis of AOAC International. 16.ed. Arlington: AOAC International, 1995. 1025p.

AYDIN, I.; UZUN, F. Nitrogen and phosphorus fertilization of rangelands affects yield, forage quality and the botanical composition. European Journal of Agronomy, v.23, p.8-14, 2005.

BAILEY, J.S. Influence of sward botanical composition on performance of cool temperate grassland under contrasting nitrogen fertilization regimes. Communications in Soil Science and Plant Analysis, v.31, p.2855-2864, 2000.

BERGERSEN, F.J. Symbiotic nitrogen fixation in legumes. In: BUTLER, G.W.; BAILEY, R.W. (Eds.) Chemistry and biochemistry of herbage. London: Academic Press, 1973. p.189-225.

BELANGER, G.; McQUEEN, R.E. Analysis of the nutritive value of timothy grown with varying $\mathrm{N}$ nutrition. Grass and Forage Science, v.53, p.109-119, 1998.

BOVAL, M.; CRUZ, P.; LEDET, J.E. et al. Effect of nitrogen on intake and digestibility of a tropical grass grazed by Creole heifers. Journal of Agricultural Science, v.138, p.73-84, 2002 .

BURNER, D.M.; MACKOWN, C.T. Nitrogen effects on herbage nitrogen use and nutritive value in a meadow and loblolly pine alley. Crop Science, v.46, n.3, p.1149-1155, 2006.

CARLSSON, G.; HUSS-DANELL, K. Nitrogen fixation in perennial forage legumes in the field. Plant and Soil, v.253, p.353-372, 2003.

CHERNEY, D.J.R.; CHERNEY, J.H.; SICILIANO-JONES, J. Alfalfa composition and in sacco fiber and protein disappearance as influenced by nitrogen application. Journal of Applied Animal Research, v.8, p.105-120, 1995.

COMAKLI, B.; MENTESE, O.; KOC, A. Nitrogen fertilizing and pre-anthesis cutting stage improve dry matter production, protein content and botanical composition in meadows. Acta Agriculturae Scandinavica Section B-Soil and Plant Science, v.55, n.2, p.125-130, 2005.

DAVIDSON, I.A.; ROBSON, M.J. The effect of temperature and nitrogen supply on the physiology of grass/clover swards. In: THOMSON, D.J. (Ed.) Forage legumes. London: British Grassland Society, 1984. p.56-60. (Occasional symposium, 16).

DELAGARDE, R.; PEYRAUD, J.L.; DELABY, L. The effect of nitrogen fertilization level and protein supplementation on herbage intake, feeding behaviour and digestion in grazing dairy cows. Animal Feed Science and Technology, v.66, p.165$180,1997$.

DURU, M. Effect of $\mathrm{N}$ fertiliser rates and defoliation regimes on the vertical structure and composition (crude protein content and digestibility) of a grass sward. Journal of the Science of Food and Agriculture, v.83, p.1469-1479, 2003.

DURU, M.; DELABY, L. The use of herbage nitrogen status to optimize herbage composition and intake and to maximize nitrogen excretion: an assessment of grazing management flexibility for dairy cows. Grass and Forage Science, v.58, p.350-361, 2003.
ELLIOTT, D.E.; ABBOTT, R.J. Nitrogen fertiliser use on rainfed pasture in the Mt Lofty Ranges, South Australia. 1. Pasture mass, composition and nutritive characteristics. Australian Journal of Experimental Agriculture, v.43, p.553-577, 2003a.

ELLIOTT, D.E.; ABBOTT, R.J. Nitrogen fertiliser use on rainfed pasture in the Mt Lofty Ranges, South Australia. 2. Responses of perennial grasses, Tama ryegrass, and sodsown oats to nitrogen fertiliser and cutting frequency. Australian Journal of Experimental Agriculture, v.43, p.579-595, 2003b.

FAO - ISRIC - ISSS. World reference base for soil resource. Rome: FAO, 1998. (World Soil Resource Reports, 84).

FRAME, J.; CHARLTON J.F.L.; LAIDLAW A.S. Temperate forage legumes. Wallingford: CAB International, 1998. 336p.

HEJCMAN, M.; KLAUDISOVA, M.; SCHELIBERG, R. et al. The Rengen grassland experiment: plant species composition after 64 years of fertilizer application. Agriculture Ecosystems and Environment, v.122, n.2, p.259-266, 2007.

HONSOVA, D.; HEJCMAN, M.; KLAUDISOVA, M. et al. Species composition of an alluvial meadow after 40 years of applying nitrogen, phosphorus and potassium fertilizer. Preslia, v.79, p.245- 258, 2007.

KEADY, T.W.J.; O'KIELY, P. An evaluation of potassium and nitrogen fertilization on grassland, and date of harvest, on fermentation, effluent production, dry-matter recovery and predicted feeding value of silage. Grass and Forage Science, v.53, p.326-337, 1998 .

LOVETT, D.K.; BORTOLOZZO, A.; CONAGHAN, P. et al. In vitro total and methane gas production as influenced by rate of nitrogen application, season of harvest and perennial ryegrass cultivar. Grass and Forage Science, v.59, p.227-232, 2004

LUO, Y.; QIN, G.; DU, G. Importance of assemblage-level thinning: A field experiment in an alpine meadow on the Tibet plateau. Journal of Vegetation Science, v.17, n.4, p.417-424, 2006.

MADAKADZE, I.C.; STEWART, K.A.; PETERSON, P.R. et al. Cutting frequency and nitrogen fertilization effects on yield and nitrogen concentration of switchgrass in a short season area. Crop Science, v.39, p.552-557, 1999.

MINISTRY OF AGRICULTURE, FISHERIES AND FOOD - MAFF. The analysis of agricultural materials. 3.ed. London: Her Majesty's Stationery Office, 1986. 248p.

MAZZANTI, A.; LEMAIRE, G.; GASTAL, F. The effect of nitrogen-fertilization upon the herbage production of tall fescue swards continuously grazed with sheep. 1. Herbage growth dynamics. Grass and Forage Science, v.49, p.111-120, 1994

McCARRICK, R.B.; WILSON, R.K. Effects of nitrogen fertilization of mixed swards on herbage yield dry matter digestibility and voluntary food intake of conserved herbages. Journal of the British Grassland Society, v.21, p.195-196, 1966.

McCAUGHEY, W.P.; SIMONS, R.G. Harvest management and $\mathrm{N}$-fertilization effects on protein yield, protein content and nitrogen use efficiency of smooth bromegrass, crested wheatgrass and meadow bromegrass. Canadian Journal of Plant Science, v.78, p.281-287, 1998.

MUELLER, L.; BEHRENDT, A.; SCHALITZ, G. et al. Above ground biomass and water use efficiency of crops at shallow water tables in a temperate climate. Agricultural Water Management, v.75, n.2, p.117-136, 2005.

MYKLESTAD, A.; SZETERSDAL, M. Effects of fertilization and afforestation on community structure of traditionally managed hay meadows in western Norway. Nordic Journal of Botany, v.23, n.5, p.593-606, 2003.

OLIVEIRA, W.S.; OLIVEIRA, P.P.A.; CORSI, M. et al. Alfalfa yield and quality as function of nitrogen fertilization and symbiosis with Sinorhizobium meliloti. Scientia Agricola, v.61, n.4, p.433-438, 2004. 
PEYRAUD, J.L.; ASTIGARRAGA, L. Review of the effect of the nitrogen fertilization on the chemical composition, intake, digestion and nutritive value of fresh herbage: consequences on animal nutrition and $\mathrm{N}$ balance. Animal Feed Science and Technology, v.72, p.235-259, 1998.

ROBSON, M.J.; RYLE, G.J.A.; WOLEDGE, J. The grass plant - its form and function. In: JONES, M.B.; LAZENBY, A. (Eds.) The grass crop: the physiological basis of production. London: Chapman \& Hall, 1988. p.129-178.

RODWELL, J.S.; DRING, J.C.; AVERIS, A.B.G. et al. Review of coverage of the national vegetation classification. Peterborough: Joint Nature Conservation Committee, 2000. 92p. (JNCC Report, 302).

STATISTICAL ANALYSIS SYSTEM - SAS. SAS/STAT ${ }^{\circledR}$ User's guide (version 8). Cary: SAS Publishing, 1999. 3809p.

SOIL SURVEY STAFF. Keys to soil taxonomy. 10.ed. Washington, D.C.: USDA-NRCS, 2006. 341p.
STEEL, R.G.D.; TORRIE, J.H. Principles and procedures of statistics. New York: McGraw Hill, 1980. 633p.

TOPP, C.F.E.; McGECHAN, M.B. Modelling productivity and nitrate leaching in a simulated dairy farm. Agronomie, v.23, p.235-247, 2003.

WILMAN, D.; FISHER, A. Effects of interval between harvests and application of fertilizer $\mathrm{N}$ in spring on the growth of perennial ryegrass in a grass white clover sward. Grass and Forage Science, v.51, p.52-57, 1996.

WILSON, J.R. Environmental and nutritional factors affecting herbage quality. In: HACKER, J.B. (Ed.) Nutritional limits to animal production from pastures. Farnham Royal: Commonwealth Agricultural Bureau, 1982. p.111131.

WOLEDGE, J. The effects of shading and cutting treatments on the photosynthetic rate of ryegrass leaves. Annals of Botany, v.41, p.1279-1286, 1977. 